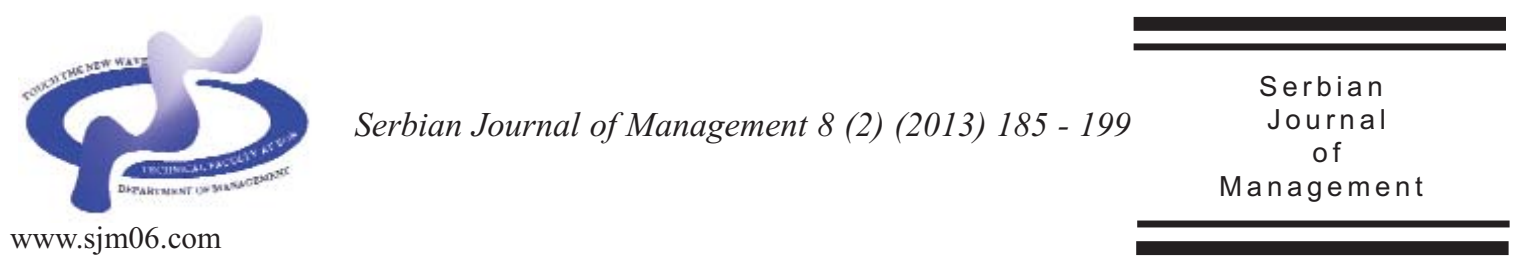

\title{
NEW GROWTH PLATFORM FRAMEWORK FOR SWISS ACUTE HOSPITALS - AN EMPIRICAL STUDY FOR THE DEVELOPMENT OF DYNAMIC CAPABILITIES
}

\author{
Zoran Alimpic* \\ Alpiq EcoServices AG, Hohlstrasse 188, CH-8026, \\ Zurich, Switzerland \\ (Received 20 May 2013; accpeted 2 October 2013)
}

\begin{abstract}
Swiss health care is confronted with fundamental changes. On the one hand, there are increasing costs in patient treatments, caused by innovative technology with new high-capacity medical devices, and a lack of effectiveness and efficiency in the organisation of a hospital. On the other hand, hospitals do have decreasing revenues with the introduction of the new patient classification and tariff system DRG (Diagnosis Related Groups) by 2012. For every DRG, hospitals will receive a fixed price, separate from the actual costs of the patient treatment. In this paper it was explored the case of 13 successful Swiss private acute hospitals which are also confronted with these pressures to reduce their costs of patient treatment and therefore to optimise their processes of care. This research focuses on dynamic capabilitie of the hospitals. Although dynamic capabilities are idiosyncratic in their details and path dependent in their emergence, they have significant 'best practise' across firms (Eisenhardt and Martin, 2000). The research is started with the evaluation of new trends, key customers' needs, and capabilities, with questionnaires for attending physicians and hospital managers. The NGP approach gives hospital managers the enough crucial information for a strategy formulation in fundamental changing environments, which is the key contribution of this manuscript.
\end{abstract}

Keywords: private acute hospitals, DRG, moderately dynamic market, sustainable competitive advantage, Switzerland

\section{INTRODUCTION - OBJECTIVE}

Health care in Switzerland traditionally has been a regulated market in a relatively simple and static market environment. On the one hand, there are the state-subsidised University and 'Cantonal' hospitals; on the other, the private hospitals that have emerged in response to the demand for enhanced health care services.

This is now changing successively. Aging population with more older and multimorbid patients, new and converging technologies, changing regulatory

\footnotetext{
* Corresponding author: zoran.alimpic@ggaweb.ch
}

DOI:10.5937/sjm8-4431 
environments, and evolving health care markets are driving the emergence of more dynamic and complex business environment. As a result, Swiss health care is embarking on a precarious path peppered with an imbalance in high costs, irregularities in the delivery of quality health care, frequent errors, and limited access to care (Porter \& Teisberg, 2006). These unsettling developments have not escaped the attention of the Swiss government. They will introduce the new finance system DRG, a patient classification system, which originated in the USA and Australia and will be customised for Switzerland means. Invariably, the implementation of DRG's will exert pressure on hospitals to increase their level of effectiveness and efficiency, to reduce their costs related to patient treatment, and to optimise their health care processes.

The impending imperative to significantly improve effectiveness and efficiency has caught most Swiss hospital managers off guard. Most have little understanding of their hospital's strategic resources, capabilities, and 'dynamic capabilities'. Yet this is precisely where they will need to focus their efforts in the future in order to sustain any position of competitiveness in the increasingly competitive Swiss health care environment regulated by DRG's. In fact, it is argued in this paper that Swiss hospitals will only achieve a position of sustainable competitive advantage by developing 'dynamic capabilities' which consists of different very important 'simple' capabilities.

It is possible to apply the RBV to dynamic market (Teece et al., 1997) however, the rationale is that RBV has not adequately explained how and why certain firms have competitive advantage in situations of rapid and unpredictable change (Eisenhardt \& Martin, 2000). Therefore, this paper will use 'dynamic capabilities' as the vehicle for an appropriate strategic response to the forces that are driving irreversible change in the Swiss health care environment through their delivery of new forms of value in the face of the changing needs of relevant stakeholders.

The dynamic capability framework is an extension of the Resource Based View (Erickson, et al., 2006, Jager et al., 2008). One of the key differences between RBV and dynamic capabilities is that the latter looks at an organisation as consisting of a bundle of capabilities - that can change - instead of a bundle of static resources (Balaji et al., 2005, Jager et al., 2008).

Identifying such crucial 'dynamic capabilities' calls for health care executives to challenge the conventional wisdom that has been at the root of their success over long periods of success in the past.

\section{THEORY}

\subsection{Dynamic capabilities in moderately dynamic markets}

A 'dynamic capability' is the capacity of an organisation to purposefully create, extend, or modify its resource base. The term 'dynamic' refers to the capacity to renew competences so as to achieve congruence with the changing business environment; certain innovative responses are required when time-to-market and timing are critical, the rate of technological change is rapid, and the nature of future competition and markets difficult to determine (Teece et al., 1997). The term 'capabilities' emphasises the key role of strategic management in appropriately adapting, integrating, and 
reconfiguring internal and external organisational skills, resources, and functional individual competences to match the requirements of a changing environment. According to Barney (1986), "it is the ability to perform a particular task or activity which must be honed to a user need, unique, and difficult to replicate" (Barney, 1986).

The original definition of 'dynamic capability' referred to 'the firm's ability to integrate, build, and reconfigure internal and external competencies to address rapidly changing environments" (Teece et al., 1997). "By altering the organisation's resource base, dynamic capabilities could then open new strategic alternatives for the firm" (Helfat, 1997). In addition, they are defined as the organisational routines " $b y$ which managers alter their resource baseacquire and shed resources, integrate them together, and recombine them to generate new value creating strategies" (Burns \& Stalker, 1966, Eisenhardt \& Martin, 2000). Dynamic capabilities are intangible processes that contribute to competitive advantage in certain environments; however, they concern change. Eisenhardt and Martin (2000) defined 'dynamic capabilities' as "the firm's processes that use resources to match and even create market change”. In this conception, 'dynamic capabilities' take the form of organisational processes to adapt the strategic management, the organisational learning and development towards the new DRG tariffs. 'Dynamic capabilities' come in many forms: some 'dynamic capabilities' help hospitals for the health care market development; other extend old ones through internal growth, acquisitions of new physicians and patients, and strategic alliances with suppliers.

Health care in Switzerland will moves from a regulated market more in the direction of a very dynamic, or what is termed 'high velocity' market. However, "health care will hardly become a high velocity market with ambiguous industry structures, blurred boundaries, fluid business models, shifting players, and no predictable and nonlinear change" which calls for a 'learning by doing' approach (Eisenhardt \& Martin, 2000). The Swiss healthcare will enter in the next few years in a 'moderately dynamic market' with a relatively stable industry structure in which change occurs frequently, but along roughly predictable and linear paths, with identifiable key players such as patients, physicians, competing hospitals and medical suppliers. In addition, it will have clear business models based on predictable outcomes, and detailed, analytical routines that rely extensively on existing knowledge. "Hospital managers will analyse situations in the context of their existing tacit knowledge and rules of thumb, and then plan and organise their activities in a relatively ordered fashion" (Burns \& Stalker, 1966), based on the 'learning before doing', approach.

\subsection{New Growth Platform (NGP)}

At the beginning it is important to analyse the health care business on a strategic level. It is suggested using the NGP framework proposed by Laurie et al. (2006) which is an option for achieving growth (Laurie et al., 2006). A platform is defined as a set of subsystems and interfaces that form a common structure from which a stream of related products can be purposefully developed, produced and delivered (Collis \& Rukstad, 2008). NGP challenge conventional management wisdom since they differ in their approach to innovation when compared 
with traditional service innovation approaches. It is first and foremost a strategic approach that focuses on building families of products, services, and businesses - that is, platforms rather than individual offerings that capture and deliver a differentiated value offering, that enable the organisation to achieve competitive advantage in its markets. Moreover, it inherently encompasses a dynamic capability component that focuses on extending existing capabilities into multiple new domains. A NGP consists of three key components as shown in figure 1 .

Key components of the NGP are as follows:

1. New market opportunities that emerge as result of changes in the competitive environment (addressing the 'what' question).

2. A clear understanding of how stakeholder's needs are changing in the evolving competitive environment (addressing the 'where' question).

3. A unified understanding on the part of the company of how it can make a difference in the emerging competitive environment (in response to the 'how' question).

\subsection{Strategic orientation}

At this stage it is important to clarify a hospital's orientation. It is difficult to find an efficient strategic approach for all hospitals due to their different medical departments. In addition they have also a different strategic approach how to compete successful in the Swiss health care market.

Measuring the strategic orientation is a major issue in strategic management studies (Huber \& Power, 1985). Snow and Hambrick (1980), according to Miles and Snow (2003)

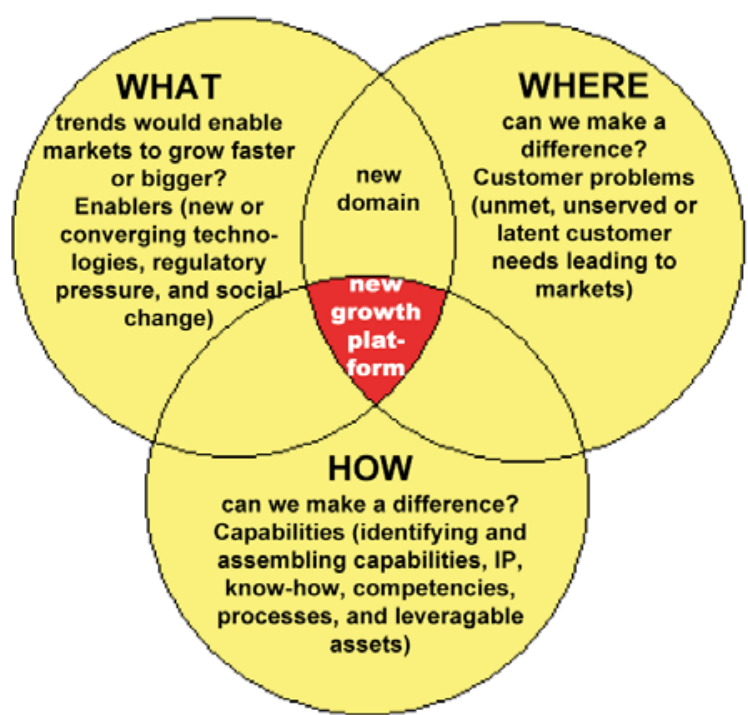

Figure 1. NGP framework, proposed by Laurie et al. (2006)

proposed the following approaches to measuring strategic orientation of a firm:

1. Self typing, where hospital's top managers characterise the strategic orientation. All 13 CEO's filled out a questionnaire, based on Miles and Snow's typology and used by different researchers such as Snow and Hrebiniak (1980), Parks (1988), Conant et al. (1990), Shortell and Zajac (1990), and Tin (2003): prospector, defender, analyser, and reactor.

2. External assessment, where external health care experts characterise the hospital's strategic orientation. A team of eight health care experts were asked to classify these 13 hospitals with the same terminology as described above.

3. Investigator inference where the researcher assess the hospital's strategic orientation, based on all available information. The first step was to classify these hospitals into their main specialisation, the second step to compare the major performance indicators: EBITDA per bed, with a hierarchical cluster analysis in SPSS. 
All methods produced the same result:

- 5 hospitals identified themselves as 'prospector' hospitals, with cardiology as major specialisation.

- 8 hospitals identified themselves as 'defender' hospitals, with orthopaedics as major specialisation.

Therefore, these 13 hospitals can be divided into two groups: five prospector and eight 'defender' hospitals.

\section{METHODS - RESEARCH METHODOLOGY}

The research of this investigation was based on a quantitative study of these 13 Swiss private hospitals. It started with an (a) PESTEL analysis with health care specialists, for the evaluation of new trends on the basis of a 5-point Likert scale. The next step was the gathering of research data with the help of a survey questionnaire that queried three of the hospital group's key stakeholder groups in each of the group's clinics - its patients, attending physicians, and managers. These in turn were then broadly allocated to one of two categories; the first grouping comprised the five prospector hospitals, while the second group comprised the eight defender hospitals.

The survey questionnaire consisted of three main constructs; these sought to identify respondents' perceptions with regard to: (b) key customers' satisfaction with 12 questions; (c) 43 capabilities that support the group's identification and analysis of trends and change in its internal and external competitive environments. Individual items queried respondents' perceptions in respect of the importance dimensions on the basis of a 5-point Likert scale.

A preliminary version of the questionnaire was tested in a pilot study in two hospitals; one in the German and the other in the French part of Switzerland. The outcomes from the pilot survey were used to make appropriate adjustments to the survey instrument before it was launched for the full-fledged investigation. The reliability scores are listet in table 1.

The last step was the collection of all data into a NGP for both hospitals groups $(\mathrm{d}+\mathrm{e})$, the five prospector und the eight defender hospitals. It includes the PCA (Principal

Component Analysis; SPSS software), which is a statistical approach, that it was used in this case to analyse the interrelationships among the very important 'simple' capabilities and to explain these variables in terms of their common underlying dimensions or factors or components (Hair et al., 2006). These components, which can be labelled as 'dynamic capabilities', are a bundle of 'simple' capabilities which permit a hospitals to 'make a living' in the short term (Winter, 2003). This approach is in line with Eisenhardt and Martin's (2000) statement that dynamic capabilities are often combinations of 'simple' capabilities and related routines, some of which may be foundational to others and so must be learned first.

\section{RESULTS}

This section is the practical evaluation of a NGP in a moderately changing environment. It starts with the external analysis and it ended with the internal evaluation of capabilities. It uses the results from the 'importance' dimension. The following five sections (analysis a-e) are the result from the questionnaire examination with the SPSS software. 


\subsection{Analysis (a): Evaluation of new trends in the Swiss health care market}

This research started with open interviews with health care specialists. The questions were about political, economic, sociocultural, technological, environmental, and legal factors as suggested in the PESTEL model. The expected result was to receive several very important factors which could have a major impact on the strategy for private hospitals. After this brainstorming, it was possible to put all factors together in a questionnaire and to ask the same people about the perceived importance with the main question: 'How significant is this factor for private hospitals in the future?' It is very interesting to see that only two trends are treated as very significant with a mean $\geq 4.5$, on a scale from 1 to 5 :

- Aging population: a demographic shift (so-called 'baby boomers') showing disproportionate growth in the segment of the population attaining higher longevity. Moreover, this segment is not only wellsituated economically; these people are prepared to pay better health care services and demand a comfortable infrastructure.

- New payment system: DRG's. Hospitals are now under pressure to initiate projects to introduce the new concept of DRG's which will be the Swiss standard in 2012.

\subsection{Analysis (b): Evaluation of key customers' needs}

The second step is the evaluation of key customers' needs with for 165 patients and 67 attending physicians in 13 private hospitals. In addition, 117 hospital managers are also interrogated to see possibly gaps between the internal and external view.

At the beginning of a strategy formulation it is always important to know the customers' needs and to include the 'voice of the customers' in the strategy formulation. In private hospitals, the key customers are patients and attending physicians. They work in hospitals; however, they are not employed by the hospitals.

The questionnaire consists of three main constructs with total 12 questions (X1-X12):

- Services (X1-X5). People in Switzerland are getting older. This is confirmed by the Swiss office for statistics (www.statistik.ch). Elderly patients, who are the key customer in hospitals, especially people with semi-private and private insurance, have another expectation of the provided service quality and hospital's facility. Therefore, it is important to ask questions about the service importance in hospitals.

- Know-how (X6-X8). The introduction of DRG's will increase the pressure on hospital's effectiveness and efficiency. Therefore, it is important that key

Table 1. Reliability scores (Cronbach's Alpha $(\alpha)$ ) for perceived 'importance' dimension

\begin{tabular}{|c|c|c|c|c|}
\hline $\begin{array}{l}\text { Dimension: } \\
\text { 'Importance' }\end{array}$ & $\begin{array}{c}\text { Five prospector } \\
\text { hospitals; sample } \\
\text { size (N) }\end{array}$ & 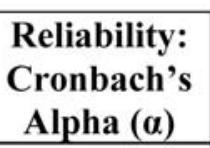 & $\begin{array}{c}\text { Eight defender } \\
\text { hospitals; sample } \\
\text { size (N) }\end{array}$ & $\begin{array}{c}\text { Reliability: } \\
\text { Cronbach's } \\
\text { Alpha }(\alpha)\end{array}$ \\
\hline Patients & 63 & 0.70 & 102 & 0.73 \\
\hline $\begin{array}{l}\text { Attending physicians } \\
\text { and hospital managers }\end{array}$ & $25+56=81$ & 0.91 & $42+61=103$ & 0.94 \\
\hline
\end{tabular}


people such as attending physicians and hospital managers have a high medical know-how.

- Infrastructure (X9-X12). The external environment analysis has shown the new expensive technology is an important factor; therefore, investments for the medical and technical infrastructure are increasing. Thus it is essential to establish an optimal infrastructure for the medical and technical staff.

The following five items perceived to be 'very important' (mean value $\geq 4.5$; scale 1 5) are:

- X1 Hospital services provided in hospital; X5 Information for key customers provided in hospital; X6 Service provided by attending physicians; X7 Knowledge of attending physicians; and X8 Cooperation and collaboration between the hospital and physicians.

Not surprisingly, therefore, the fact is that the Swiss private hospital group's key customers value excellent medical services and a high degree of know how from both the physicians and staff within the hospital. This result is confirmed by the same results from hospitals' managers' questionnaires.

Finally, the new key customers' needs are based on these five points above. It is important that the hospitals services and the support from physicians are superior. In addition, it is essential that the staff and the attending physicians have an excellent medical knowledge and that their coordination and collaboration are organised very well.

\subsection{Analysis (c): Identification of capabilities}

The survey questionnaire's in appendix queried 43 'simple' capabilities. Key customers, in this case these patients and attending physicians, answered these questions. There are not significant variance between attending physicians and hospital managers (employees).

The following eleven items in the five prospector hospitals, perceived to be 'very important' (mean value $\geq 4.5$; scale $1-5$ ), are:

- X13 Relationship of hospitals with attending physicians; X15 Relationship of hospitals with patients; X18 Relationship of hospitals with insurance companies; X21 Reputation and brand of the hospital; X24 Ability of the hospital to widen the customer base through focused market penetration and development; X32 Acquisition process for finding new patients with additional insurance; X36 Visionary, capable leadership; X37 Decision making process in clinic; X44 Quality management in clinic; X48 Effective cooperation with attending physicians; and X54 Development of medical infrastructure of the clinic.

The following eight items in the eight defender hospitals, perceived to be 'very important' (mean value $\geq 4.5$; scale 1-5), are:

- X13 Relationship of hospitals with attending physicians; X15 Relationship of hospitals with patients; X18 Relationship of hospitals with insurance companies; X21 Reputation and brand of the hospital; X36 Visionary, capable leadership; X45 Nurturing of the culture for working in clinic; X47 Communication between management and staff; and X48 Effective cooperation with attending physicians.

The differences between both hospitals groups are:

- Five prospector hospitals have a tension on 'marketing' and 'infrastructure development'.

- Eight defender hospitals have a tension on 'culture'. 


\subsection{Analysis (d): NGP for five prospector hospitals}

The following NGP summarises the results from the three previous sections (analysis a-c) for the five prospector hospitals (Figure 2).

These eleven 'simple' capabilities form a bundle of very important capabilities which meets key customers' needs and forces of change in the greater competitive environment. However, these capabilities cannot be interpreted separately due to the fact that they are all linked together.

The following factor analysis is an essay to bundle these eleven capabilities. The desired result is to reduce the number of capabilities which can be better handled. This is the starting point for the development of 'dynamic capabilities'.

With a KMO (Kaiser-Meyer-Olkin) value of 0.70 , a significance of 0.000 , and a loading $\geq 0.7$, the results are as follows:
- X37 Decision making process in clinic; X36 Visionary, capable leadership; X18 Relationship of hospitals with insurance companies; X48 Effective cooperation with attending physicians; and X15 Relationship of hospitals with patients.

These five 'simple' capabilities describe about $56 \%$ of the population (rotation sums of squared loadings; cumulative \%).

\subsection{Analysis (e): NGP for eight defender hospitals}

The following NGP summarises the results from the previous sections (analysis a-c) for the eight defender hospitals (Figure $3)$.

These eight 'simple' capabilities form a bundle of very important capabilities which meets key customers' needs and forces of change in the greater competitive environment. As described in the section above, this evaluation is the starting point for

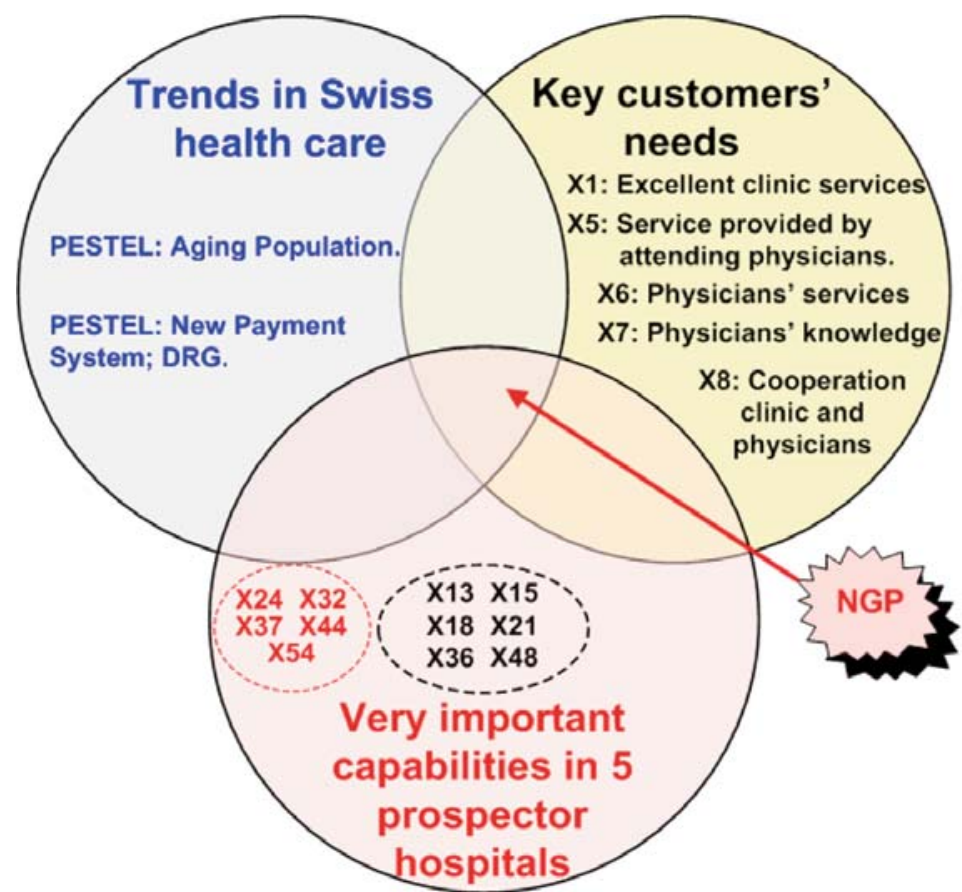

X13: Relationship of clinic with attending physicians.

X15: Relationship of clinic with patients.

X18: Relationship of clinic with insurance companies.

X21: Reputation/ image / brand/ label of the clinic.

X36: Visionary, capable leadership in clinic.

X48: Cooperation with physicians in clinic.

X24: Ability to widen the customer base through focused market penetration and development.

X32: Acquisition-process for finding new patients with additional insurance. X37: Decision making process in clinic.

X44: Quality management in clinic.

X54: Development of medical infrastructure of the clinic.

Figure 2. NGP for 5 prospector hospitals 
the development of 'dynamic capabilities'.

With a KMO (Kaiser-Meyer-Olkin) value of 0.70 , a significance of 0.000 , and a loading $\geq 0.7$, the results are as follows:

- X47 Communication between management and staff; X45 Nurturing of the culture for working in clinic; X21 Reputation and brand of the hospital; X15 Relationship of hospitals with patients; X18 Relationship of hospitals with insurance companies; and X13 Relationship of hospitals with attending physicians.

These six 'simple' capabilities describe about $61 \%$ of the population (rotation sums of squared loadings; cumulative \%).

\section{DISCUSSION}

The analysis with the NGP approach has shown a clear picture of both hospitals groups which can be illustrated as follows (Table 2).
This table 2 contains crucial information how to react on new trends:

- For the aging population it is important to improve hospitals' and physicians' services and to provide more information for key customers. The future strategy in prospector hospitals is to have an effective decision making and visionary leadership. Both points are part of a dynamic capability which can manage change in a moderately dynamic market. In contrast, the defender hospitals have to be focused on better communication and culture to improve the reputation. In this case, the dynamic capability is to have a strong brand and thus to manage change.

- With the introduction of DRG's it is important to have an effective cooperation with physicians to benefit from their medical knowledge. The future strategy in prospector as well as in defender hospitals is to have a good relationship with key customers such as patients and physicians. This is the basis to

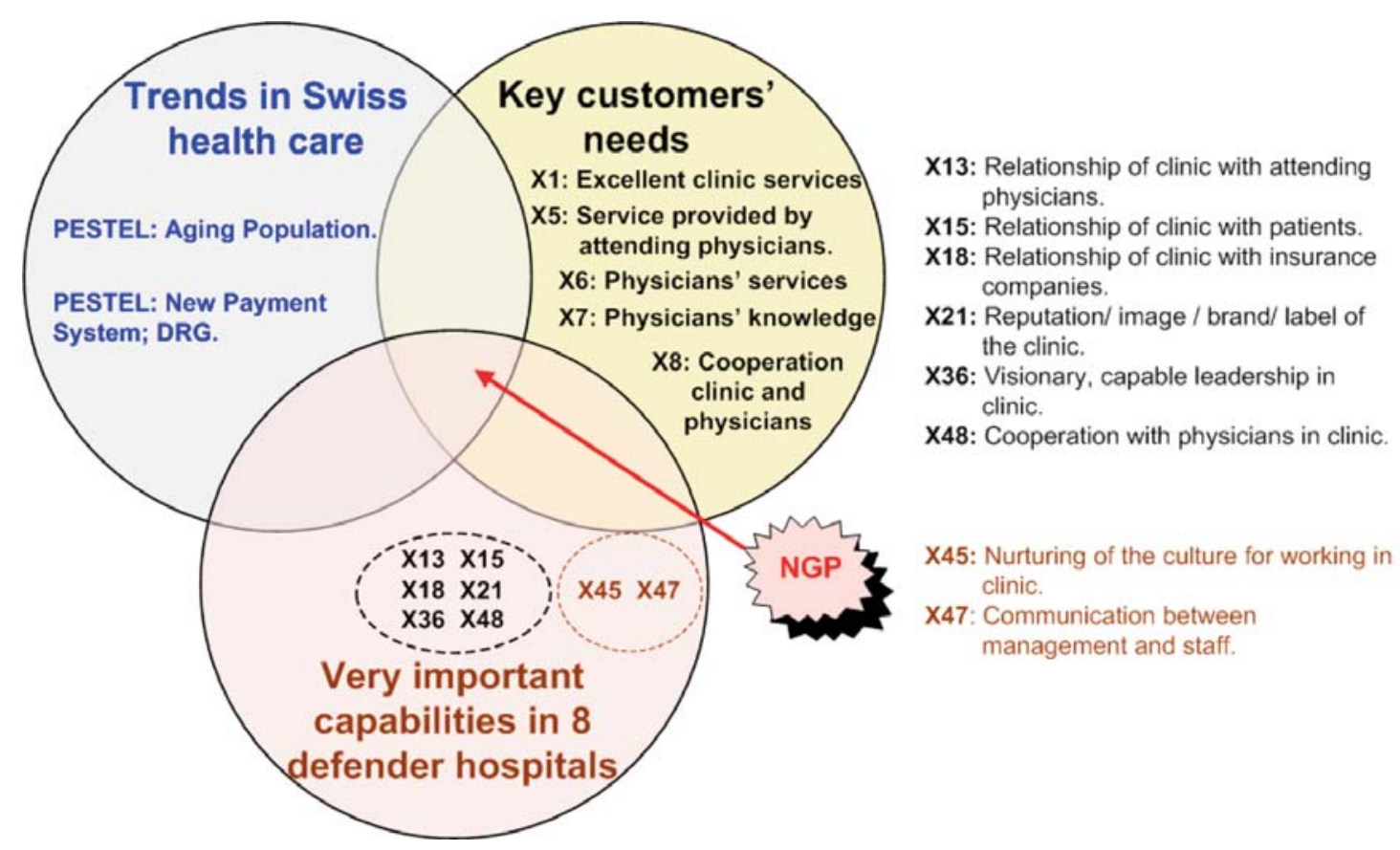

Figure 3. NGP for 8 defender hospitals 
Table 2. NGP with crucial information for private hospitals

\begin{tabular}{|l|l|l|}
\hline $\begin{array}{l}\text { WHAT trends would enable } \\
\text { group's markets to grow } \\
\text { faster and bigger? }\end{array}$ & $\begin{array}{l}\text { WHERE can the } \\
\text { hospital groups make a } \\
\text { difference? }\end{array}$ & $\begin{array}{l}\text { HOW can both hospital groups make a difference } \\
\text { on the basis of its dynamic capabilities? }\end{array}$ \\
\hline Aging population & $\begin{array}{l}\text { Excellent hospital } \\
\text { services provided in } \\
\text { hospital (X1); effective } \\
\text { information management } \\
\text { for key customers (X5); } \\
\text { and excellent service } \\
\text { provided by attending } \\
\text { physicians (X6). }\end{array}$ & $\begin{array}{l}\text { Focus in five prospector hospitals is on: } \\
\text { Effective decision making (X37), and visionary } \\
\text { leadership (X36). } \\
\text { Focus in eight defender hospitals is on: } \\
\text { Communication between management and staff } \\
\text { (X47); Nurturing of the culture for working in clinic } \\
\text { (X45); Reputation and brand of the hospital (X21); }\end{array}$ \\
\hline New payment system DRG & $\begin{array}{l}\text { Utilisation of the high- } \\
\text { level medical knowledge } \\
\text { of the attending } \\
\text { physicians (X7), and } \\
\text { cooperation with } \\
\text { physicians (X8). }\end{array}$ & $\begin{array}{l}\text { Focus in five prospector hospitals is on: } \\
\text { Good relationship with insurance companies (X18), } \\
\text { effective cooperation with attending physicians } \\
\text { (X48), and good relationship with patients (X15). } \\
\text { Focus in eight defender hospitals is on: } \\
\text { Good relationship with patients (X15), insurance } \\
\text { companies (X18); and attending physicians (X13). }\end{array}$ \\
\hline
\end{tabular}

start a mutually beneficial negotiation with insurance companies regarding the new tariffs. This leads to the dynamic capability to charge always the maximum und thus to become the cost leader in the health care sector.

Hospitals managers have the choice now 'to do nothing', to rely on 'ad hoc problem solving' within the different medical departments, and thus to minimise costs, or to invest in 'dynamic capabilities' based on a 'best practise' approach. The former possibility may bring positive short-term results in departments, but not the expected long-term success after the DRG implementation with the intended increase of effectiveness and efficiency in the organisation of the entire hospital. Therefore, it is proposed to invest in 'dynamic capabilities' which is the key to competitive advantage (Teece et al., 1997).

The first step of implementation is to understand and improve the 'simple' capabilities which shape together a dynamic capability. Brown and Eisenhardt (1997) termed this property 'sequenced steps' with "learning from the 'simple' and more predictable capabilities around management, services, processes, and relationships in hospitals". Therefore, dynamic capabilities consist of many wellknown processes that have to be studied extensively. "Their value for competitive advantage lies in their ability to alter the resource base: create, integrate, recombine, and release resources" (Eisenhardt \& Martin, 2000). They are thus not robust processes which lead per se to sustainable competitive advantage. It is the "best practise process in moderate dynamic markets" which is essential: to know which dynamic capabilities have an influence on performance, their constitution of different 'simple' capabilities, the well-known learning mechanism how to modify the capabilities, and the resource configuration that hospital managers build using such dynamic capabilities.

The second step is to leverage such dynamic capabilities, within the hospital or between hospitals, which leads to lower costs and time savings. According to Sirmon 
et al. (2007), "leveraging refers to the application of a firm's capabilities to create value for customers and wealth for owners" (Sirmon et al., 2007). In hospitals the leverage by knowledge combination emphasises the creation of new know-how and thus reduces the probability of core rigidities. This means combining knowledge with other dynamic capabilities. Furthermore, knowledge and capabilities can be leveraged in a way which enables to increase the level of performance as well as eventually economies of scope and scale. Such "combinative capabilities may contribute to the resolution of the hospitals" permanent struggle to find the right balance between exploration and exploitation as knowledge combination is simultaneous exploration as well as exploitation" (Argot, 1999). Effective leveraging of the hospital's capabilities will result in organisational learning and a culture of capability adaptation to meet the expectations of key customers' needs.

\section{CONCLUSION}

Swiss health care is changing from a regulated market, with standardised tariffs and relatively static market environment, to a moderately dynamic market. Hospitals are forced to improve their services and to increase the level of know how in view of the new payment system DRG by 2012. The main target must be to have a higher effectiveness and efficiency and thus to reach sustainable competitive advantage. One approach can help to reach this ambitious target. It is the finding of dynamic capabilities which can help to build a bridge between the current and the future situation. This article described 'dynamic capabilities' as 'bundles of simple capabilities', which can alter the resource configuration based on a 'best-practise' and 'learning before doing' approach.

The NGP is used for the strategic analysis. It gives hospital managers the following crucial information for a strategy formulation in changing environments:

1. From the environmental analysis, it highlights new trends in the health care sector: The aging population, and the new payment system DRG.

2. Based on a questionnaire survey, it shows that patients and attending physicians - as key customers - value excellent medical services and a high degree of know how from both the physicians and staff within a hospital.

3. Based on a questionnaire survey, it shows that from 43 'simple' capabilities only eleven items in the five prospector hospitals are valued as 'very important' (mean value $>$ 4.5; scale 1-5). In the eight defender hospitals there are only eight very important capabilities.

4. With a factor analysis it was possible to reduce in prospector hospitals the number of capabilities again. The results are the following five key capabilities which are the basis for dynamic capabilities: Decision making, visionary leadership, relationship with insurance companies, cooperation with physicians, and relationship with patients.

5. The factor analysis showed the following six capabilities in defender hospitals: communication, culture, reputation, and relationship with patients, insurance companies and physicians.

This investigation has shown that different capabilities form together clusters which can be seen as dynamic capabilities. They are not robust processes which lead per se to sustainable competitive advantage; they are 'best practise processes in moderate 
dynamic markets' which goal is a series of temporary competitive advantage. Another important aspect is the leverage of dynamic capabilities by knowledge combination for the creation of new know-how. Effective leveraging of the hospital's capabilities will result in organisational learning and a culture of capability adaptation to meet the expectations of key customers' needs. With an efficient management of 'dynamic capabilities', hospitals can improve all processes and thus increase the level of knowledge. This leads to a higher customer satisfaction and a better reputation which helps to outperform competitors and to reach sustainable competitive advantage - also in moderate dynamic markets.

\section{References}

Barney, J.B. (1986). Organizational culture: can it be a source of sustained competitive advantage? Academy of Management Review, 11(3):656-665.

Collis, D.J., \& Rukstad, M.G. (2008). Can you say what your Strategy is? Harvard Business Review: 1-9.

Conant, J.S., Mokwa, M.P., \& Varadarajan, P.R. (1990). Strategic types, distinctive marketing competencies and organisational performance: A multiple measures-based study. Strategic Management Journal, 11 (5): 365-383.

Eisenhardt, K.M., \& Martin, J.A. (2000). Dynamic Capabilities: What are they?

\title{
ОКВИР НОВЕ ПЛАТФОРМЕ РАСТА ЗА ШВАЈЦАРСКЕ АКУТНЕ БОЛНИЦЕ - ЕМПИРИЈСКА СТУДИЈЕ РАЗВОЈА ДИНАМИЧКИХ МОГУЋНОСТИ
}

\author{
Зоран Алимпић
}

\section{Извод}

Швајцарски здравствени систем се суочава са фундаменталним променама. Са једне стране јављају се повећани трошкови третмана пацијената, изазвани иновативним технологијама са медицинском опремом вишег капацитета али и недостатком ефективности и ефикасности у организацији болница. С друге стране, болнице имају пад прихода увођењем нове класификације пацијената и тарифног система Група повезаних Дијагноза “ДРГ” током 2012. Овим системом, болнице имају фиксну цену, независно од стварних трошкова лечења пацијената. У овом раду је изучаван случај 13 успешних швајцарских приватних акутних болница, које се такође сусрећу са притиском да смање своје трошкове третмана пацијената и да оптимизирају свој процес рада. Истраживање се односи на динамичке капацитете самих болница. Истраживање је започело уз евалуацију нових трендова, кључних жеља клијената и капацитета, коришћењем упитника за испитивање запошљених лекара и менаџера болнице. како би се анализирала међузависност важних могућности са основама за развој динамичких могућности, рађена је метода анализе основних компоненти. Овај приступ даје могућност менаџерима болница значајне кључне информације за формулисање стратегије у окружењу које је динамичко и промењиво, што је и главни допринос овог рада.

Кључне речи: приватне акутне болнице, ДРГ, савремено динамичко тржиште, конкурентска предност, Швајцарска 
Strategic Management Journal, 21: 1105- the black box. Academy of Management 1121.

Review, 32(1): 273-292.

Hair, J.F., Black, W.C., Babin, B.J.,

Teece, D.J., Pisano, G., \& Shuen, A. Anderson, R.E., \& Tatham, R.L. (2006). Multivariate Data Analysis. 6th Edition. Upper Saddle River, NJ: Pearson/Prentice Hall.

Helfat, C.E., Finkelstein, S., Mitchell, W., Peteraf, M.A., Singh, H., Teece, D.J., \& Winter, S.G. (2007). Dynamic Capabilities: Understanding Strategic Change in Organizations. Oxford: Blackwell Publishing. (1997). Dynamic Capabilities and Strategic Management. Strategic Management Journal, 18(7): 509-533.

Tin, T.J. (2003). An empirical study of medium to large-sized companies in Singapore - Environment, Competency, Strategy types and Performance. Docoral dissertation, The Henley Management College, Brunel - The University of West London.

Huber, G. \& Power, D. (1985). Retrospective Reports of Strategic-level Managers: Guidelines for Increasing Their Winter, S.G. (2003). Understanding dynamic capabilities. Strategic Management Journal, 24(10): 991-995.

Accuracy. Research Notes, 6: 171-180.

Jager, C.J., Vos, S., Borgers, M., Harmsen, F., Brinkkemper, S., \& Wijngaert, L., (2008). Controlling risk prior to offshore application development. Department of Information and Computing Sciences, Utrecht University, Technical Report UUCS-2008-009, ISSN: 0924-3275.

Laurie, D.L., Doz, Y.L., \& Sheer, C.P. (2006). Creating New Growth Platforms. Harvard Business Review, 84(5): 80-90.

Miles, R.E, \& Snow, C.C. (2003). Organisational Strategy, Structure, and Process. 2nd edition. California: Stanford Business Books, University Press, Stanford.

Parks, D.M. (1988). Business Level Strategy, Competitive Forces, and Performance; an empirical study of mid-size manufacturing firms. Docoral dissertation, Texas A\&M University.

Porter, M.E., \& Teisberg, E.O. (2006). Redefining Health Care: Creating ValueBased Competition on Results. Boston: Harvard Business School Press.

Sirmon, D.G., Hitt, M.A., \& Ireland, R.D. (2007). Managing firm resources in dynamic environments to create value: looking inside 
Table A1: Questionnaire, 1. Part: capabilities in hospitals

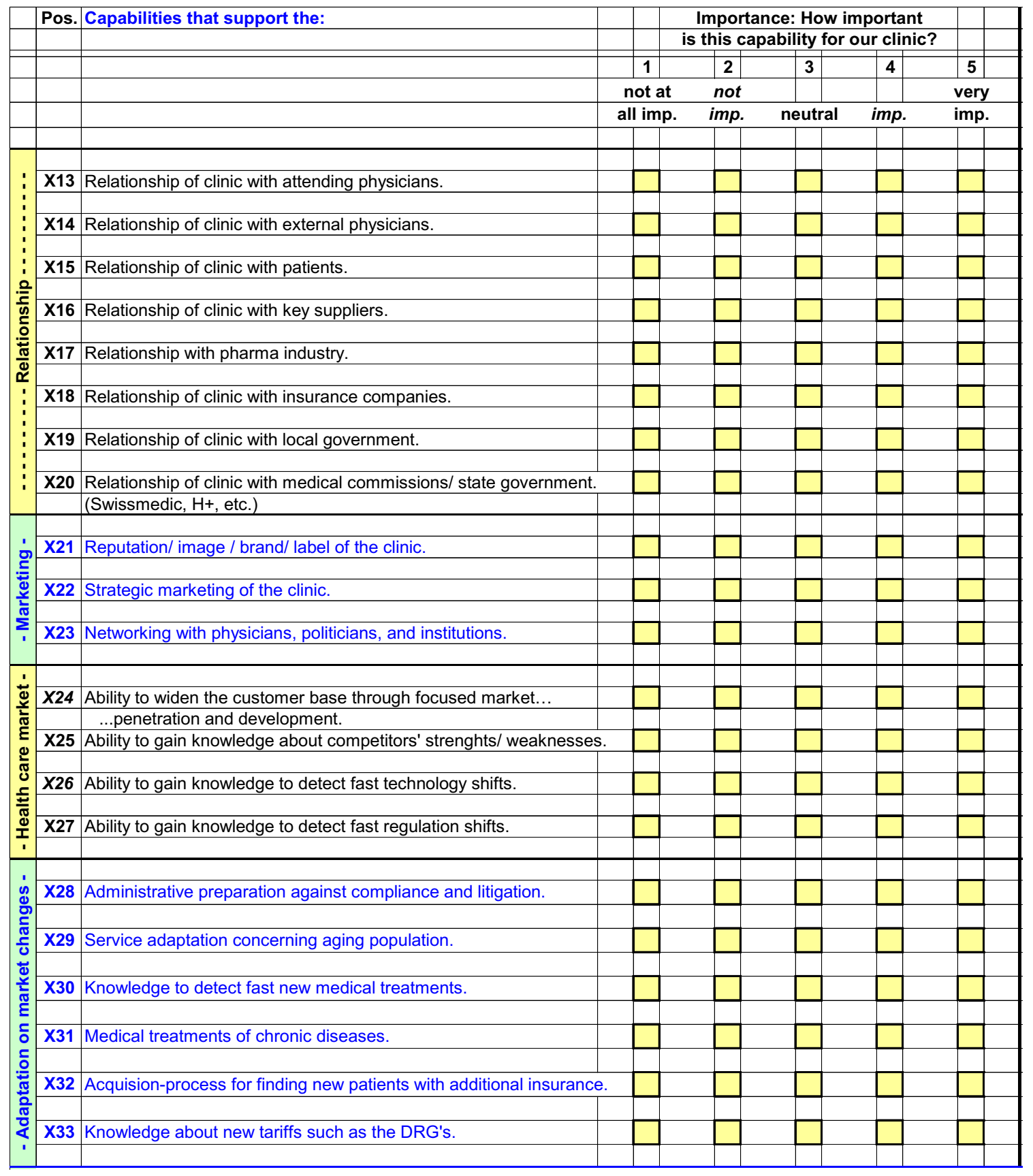


Table A2: Questionnaire, 2. Part: capabilities in hospitals

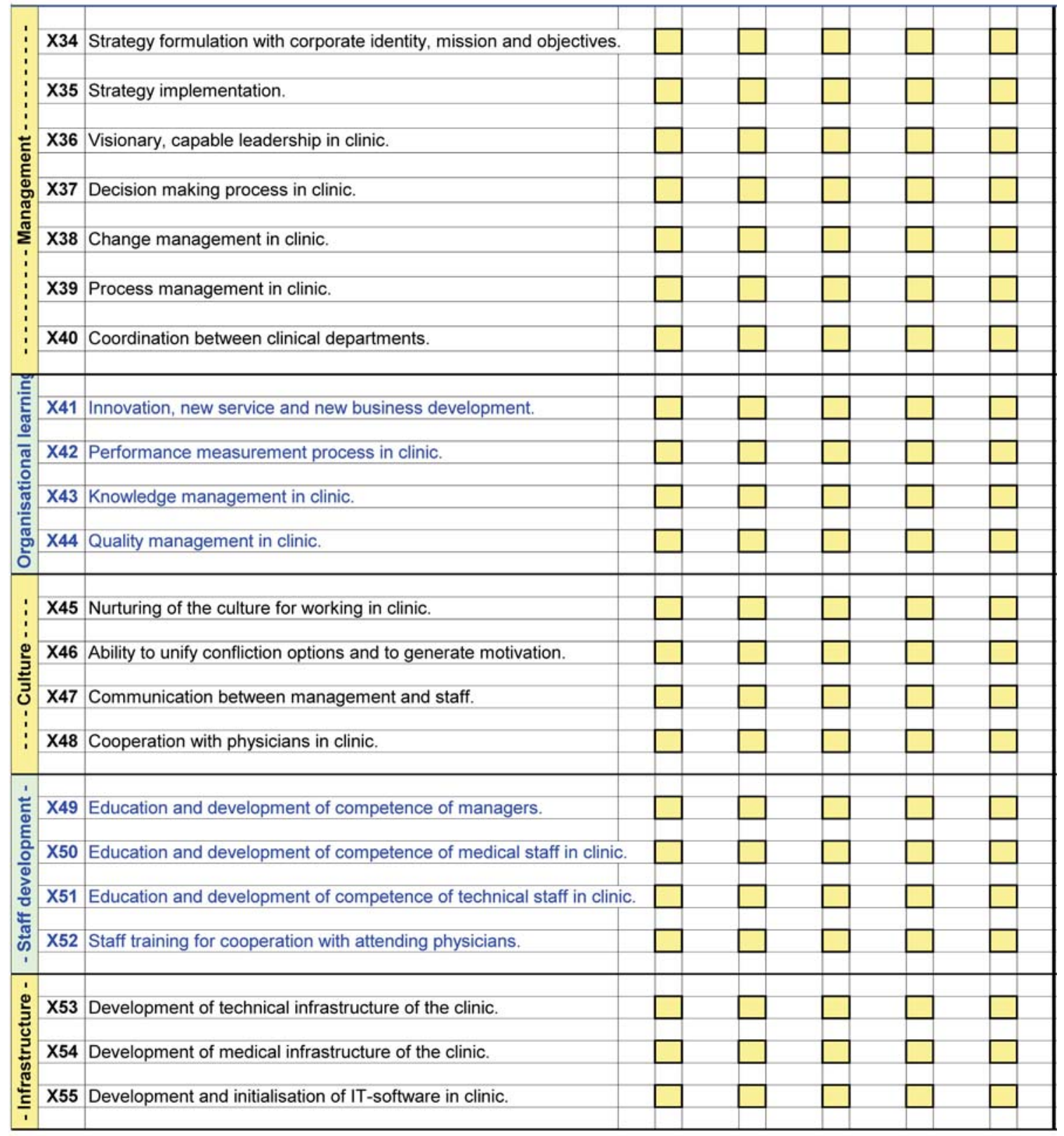

